\title{
Hepatoma-derived growth factor: from the bovine uterus to the in vitro embryo culture
}

\author{
E Gómez, E Correia-Álvarez, J N Caamaño, C Díez, S Carrocera, N Peynot ${ }^{1}$, D Martín, \\ C Giraud-Delville ${ }^{1}$, V Duranthon ${ }^{1}$, O Sandra ${ }^{1}$ and $M$ Muñoz
}

Área de Genética y Reproducción Animal, Centro de Biotecnología Animal - SERIDA, Camino de Rioseco 1225, La Olla - Deva, 33394 Gijón, Asturias, Spain and ${ }^{1}$ INRA, UMR1198 Biologie du Développement et Reproduction, F-78350 Jouy-en-Josas, France

Correspondence should be addressed to E Gómez; Email: egomez@serida.org

\begin{abstract}
Early in cow embryo development, hepatoma-derived growth factor (HDGF) is detectable in uterine fluid. The origin of HDGF in maternal tissues is unknown, as is the effect of the induction on developing embryos. Herein, we analyze HDGF expression in day 8 endometrium exposed to embryos, as well as the effects of recombinant HDGF (rHDGF) on embryo growth. Exposure to embryos did not alter endometrial levels of $H D G F m R N A$ or protein. HDGF protein localized to cell nuclei in the luminal epithelium and superficial glands and to the apical cytoplasm in deep glands. After uterine passage, levels of embryonic HDGF mRNA decreased and HDGF protein was detected only in the trophectoderm. In fetal fibroblast cultures, addition of rHDGF promoted cell proliferation. In experiments with group cultures of morulae in protein-free medium containing polyvinyl alcohol, adding rHDGF inhibited blastocyst development and did not affect cell counts when the morulae were early (day 5), whereas it enhanced blastocyst development and increased cell counts when the morulae were compact (day 6). In cultures of individual day 6 morulae, adding rHDGF promoted blastocyst development and increased cell counts. Our experiments with rHDGF indicate that the growth factor stimulates embryonic development and cell proliferation. HDGF is synthesized similarly by the endometrium and embryo, and it may exert embryotropic effects by autocrine and/or paracrine mechanisms.

Reproduction (2014) $\mathbf{1 4 8} 353-365$
\end{abstract}

\section{Introduction}

The acidic, heparin-binding protein hepatoma-derived growth factor (HDGF) was originally isolated from a conditioned medium of human hepatoma cells (Nakamura et al. 1994). HDGF is a multifunctional protein that participates in the regulation of many cellular events, including ribosome biogenesis, RNA processing, DNA damage repair, and transcription (Zhao et al. 2011). Exogenous HDGF promotes proliferation of numerous cell types (e.g. vascular smooth muscle and endothelial and fibroblast cells; Klagsbrun et al. 1986, Everett et al. 2001), including cancer cell lines (Bernard et al. 2003, Hu et al. 2003, Chang et al. 2007, Lee et al. 2010, Liao et al. 2010, Yang et al. 2013). In tumor cells, overexpressed HDGF increases proliferation, migration, and neoangiogenesis (Sasaki et al. 2011, Thirant et al. 2012, Tsai et al. 2013), and it inhibits apoptosis (Lee et al. 2010, Liao et al. 2010).

HDGF is involved in organ development and tissue differentiation (Oliver \& Al-Awqati 1998, Everett 2001, Everett et al. 2001, Enomoto et al. 2002). The molecular details of how HDGF influences development remain unclear because membrane or nuclear receptors for
HDGF have yet to be identified. Nevertheless, it does appear that this soluble factor promotes remodeling by activating the phosphatidylinositol 3-kinase (PI3K)/Akt signaling pathway (Kung et al. 2012). Factors regulating HDGF gene expression and activity also remain unclear, though studies indicate that restoring p53 activity in cancer cells represses transcription of the HDGF gene (Sasaki et al. 2011).

In the bovine species, previous studies have already identified numerous growth factors produced by the reproductive tract, which improve in vitro embryo development. These include insulin-like growth factor 1 (IGF1), epidermal growth factor (EGF), activin, granulocyte-macrophage colony-stimulating factor (GMCSF or CSF2), hyaluronan, fibroblast growth factor 2 (FGF2), and platelet-activating factor (PAF) (Gopichandran \& Leese 2006, Block et al. 2011, Bonilla et al. 2011, Fields et al. 2011, Trigal et al. 2011, Sakagami et al. 2012). CSF2 has also been shown to act during gastrulation development (Loureiro et al. 2009, 2011). Several of these growth factors have been shown to improve survival-to-term following embryo transfer, including EGF, CSF2, CSF3, IGF1, and hyaluronan (Lim et al. 2007, 
Loureiro et al. 2009, Block et al. 2011, Sakagami et al. 2012). In a previous study combining two-dimensional difference gel electrophoresis with liquid chromatography-electrospray ionization mass spectrometry, we identified HDGF among 23 proteins that were overexpressed in day 8 uterine fluid (UF) collected from pregnant cows (Muñoz et al. 2012). This suggests that this growth factor may be involved in the regulation of blastocyst development, prompting the need for i) a detailed analysis of HDGF gene expression and ii) first investigation of the biological actions this growth factor will exert at the endometrium-embryo interface during early pregnancy.

In this study, we examined the origin of lumenal HDGF by determining the endometrial and embryonic localization of the protein and gene expression during transient in utero development of embryos produced in vitro. We also analyzed the bioactivity of recombinant HDGF (rHDGF) on fetal fibroblast cell proliferation and its effects on the in vitro development of bovine embryos.

\section{Materials and methods}

All chemicals were purchased from Sigma, unless otherwise indicated.

\begin{abstract}
Animals
All experimental procedures with animals were carried out according to the European Community Directive 2010/63/EU (Spanish Regulation R.D. 53/2013) and were approved by the Animal Research Ethics Committee of SERIDA.

The experimental design has been described previously (Muñoz et al. 2012). Briefly, crossbred, age-matched, mixed heifers (Asturiana de los Valles and Asturiana de la Montaña cross, $n=6)$ and uniparous cows $(n=5)$ were synchronized to estrus (day 0) by using an intravaginal progesterone device (PRID ALPHA, Ceva, Barcelona, Spain) for 10 days combined with a prostaglandin analog (Dynolitic, Pfizer) injected $48 \mathrm{~h}$ before progestagen removal. Animals were assigned to either a cyclic group $(n=6)$ or an in vitro-produced (IVP) group $(n=5)$. The IVP group received 50 IVP embryos on day 5 (Gómez et al. 2013), while the cyclic group underwent sham transfer. Animals were killed in a nearby slaughterhouse (Matadero de Pravia, Asturias, Spain) on day 8 of their cycle.

Uterine horns were flushed, and the presence of embryos at appropriate development stages was examined in washes from embryo-transferred females. Endometrial samples and embryos were processed as described below.
\end{abstract}

\section{Endometrial sample collection}

Genital apparatuses were transported to the laboratory at $4{ }^{\circ} \mathrm{C}$, and middle and cranial thirds were sampled as described previously (Gómez et al. 2013). Briefly, endometrial crosssections were taken from caruncular and intercaruncular regions from the horn ipsilateral to the corpus luteum. Samples were processed for immunohistochemistry (IHC), western blotting (WB), and mRNA expression analysis. For WB and RT-PCR analysis, the caruncular and intercaruncular endometria, including deep endometrial glands, were dissected from the underlying myometrium. To allow for histological evaluation of the endometrium, IHC samples were fixed overnight at $4{ }^{\circ} \mathrm{C}$ in $4 \%$ paraformaldehyde in $0.1 \mathrm{M}$ PBS $(8.1 \mathrm{mM}$ sodium phosphate dibasic, $137.9 \mathrm{mM}$ sodium chloride, $2.07 \mathrm{mM}$ potassium chloride, and $1.5 \mathrm{mM}$ potassium phosphate monobasic; $\mathrm{pH}$ 7.4), dehydrated, embedded in paraffin, sectioned to a thickness of $4 \mu \mathrm{m}$, and stained with hematoxylin and eosin (Panreac, Barcelona, Spain).

Samples collected for WB were snap frozen in liquid nitrogen and stored at $-145{ }^{\circ} \mathrm{C}$ until homogenization. Endometrial tissue was homogenized using a high-intensity ultrasonic processor (Sonics \& Materials, Newton, MA, USA) in $10 \mathrm{ml}$ lysis buffer (CelLytic, Sigma, Madrid, Spain, MT C3228) and $50 \mu$ l protease inhibitors (P8340, Sigma) per gram of tissue. After centrifugation at $3026 \mathrm{~g}$ for $10 \mathrm{~min}$ at $4^{\circ} \mathrm{C}$, the supernatant was collected and stored at $-145^{\circ} \mathrm{C}$. Total protein concentration in tissue lysates was analyzed using the Quick Start Bradford protein assay kit (Bio-Rad Laboratories).

Samples for mRNA expression analysis with quantitative real-time reverse transcriptase PCR (qRT-PCR) were incubated overnight at $4{ }^{\circ} \mathrm{C}$ in RNAlater (Ambion, Huntingdon, Cambridgeshire, UK). Subsequently, excess RNAlater was removed and samples were stored at $-145^{\circ} \mathrm{C}$ until use.

\section{Analysis of HDGF protein levels in bovine endometrium by IHC}

Cell-specific expression of HDGF was analyzed with a mouse polyclonal antibody against $\operatorname{HDGF}$ (43668, Abcam, Cambridge, UK; diluted 1:1000) in endometrial cross-sections following a classical immunostaining protocol (Muñoz et al. 2005). Immunostained sections were rinsed in tap water, counterstained using modified Harris hematoxylin solution (AHHSS16), cleared, and mounted. Images of representative fields were recorded under bright-field illumination using an Olympus BX51 microscope fitted with an Olympus DP70 digital camera. Positive immunostaining was scored by two independent observers blind to the nature of the tissue. Negative control sections were incubated with $5 \%$ normal blocking serum instead of the primary antibody. No significant positive staining was observed in negative control sections (data not shown).

\section{Analysis of HDGF protein levels in bovine endometrium by $W B$}

Immunoblotting was performed as described previously (Muñoz et al. 2012). Briefly, total endometrial protein $(5 \mu \mathrm{g} /$ sample) was electrophoresed on $12 \%$ SDS-PAGE gels. Proteins were then transferred electrically onto a PVDF membrane (Millipore, Billerica, MA, USA), which was incubated with a mouse polyclonal antibody against HDGF (43668, Abcam; diluted 1:1500) and a mouse MAB against $\beta$-actin (2228, Sigma; diluted 1:6600). After washing, the membrane was incubated with the required secondary antibody (goat antimouse/HRP conjugate; Amersham Pharmacia Biotech) at 1:4000 dilution and detected using the Pierce ECL or ECL 
plus detection kits (Thermo Scientific, Waltham, MA, USA). Protein levels were quantified using scanning densitometry and the ImageJ Software (http://rsbweb.nih.gov/ij/), with three replicate lanes quantified per biological condition. Differences in mean protein abundance were analyzed and expressed as fold change (least square mean (LSM) \pm s.E.M.). As levels of $\beta$-actin vary significantly across uterus regions and even between replicate samples, protein expression was normalized based on protein loading visualized by Coomassie staining.

\section{Analysis of HDGF mRNA levels in bovine endometrium by real-time $R T$-PCR}

Total RNA from frozen endometrial tissue was extracted and purified, and its quality was assessed as described previously (Mansouri-Attia et al. 2009). Total purified RNA (1 $\mu \mathrm{g})$ was reverse transcribed in a final reaction volume of $20 \mu \mathrm{l}$ using Superscript III enzyme (Invitrogen) and random primers (Roche). Reaction conditions were $65^{\circ} \mathrm{C}$ for $10 \mathrm{~min}$ followed by 5 min cooling on ice to allow annealing, $42{ }^{\circ} \mathrm{C}$ for $50 \mathrm{~min}$ to allow synthesis, and finally $70{ }^{\circ} \mathrm{C}$ for $15 \mathrm{~min}$ to denature the enzyme.

This reverse-transcribed DNA was then subjected to realtime RT-PCR using primers targeting the HDGF gene or one of the following reference genes: $\beta$-actin $(A C T B(A C T))$; chromosome 11 open reading frame, human C2orf29 (CNOT11 (C2ORF29)); glyceraldehyde 3-phosphate dehydrogenase $(G A P D H)$; ribosomal protein L19 (RPL19); solute carrier family 30 (zinc transporter), member 6 (SLC3OA6); and succinate dehydrogenase flavoprotein subunit A (SDHA). Primers for all genes were designed using Primer Express version 3.0 (Applied Biosystems; Table 1). Real-time PCRs were carried out using Master Mix SYBR Green and the Step One Plus system (Applied Biosystems), in a total volume of $15 \mu$ l containing $5 \mu \mathrm{l}$ cDNA (diluted 1:200) and $0.3 \mu \mathrm{M}$ primers. Amplification conditions were as follows: $50{ }^{\circ} \mathrm{C}$ for $2 \mathrm{~min}, 95^{\circ} \mathrm{C}$ for $10 \mathrm{~min}$, 45 cycles at $95^{\circ} \mathrm{C}$ for $15 \mathrm{~s}$ (denaturation), and $60{ }^{\circ} \mathrm{C}$ for $1 \mathrm{~min}$ (primer annealing and extension). Melting curve analyses were performed immediately after amplification; all samples were analyzed on the same plate to minimize variation between runs. A calibration curve was produced using cDNA retrotranscribed from total RNA pooled from all endometrial samples (several replicates) and serially diluted as described previously (Mansouri-Attia et al. 2009).

All samples were reverse transcribed and amplified in duplicate. Negative control samples for each gene were run in parallel without template or without primers. None of the negative control reactions showed amplicons. Amplicon sequences for all target genes were verified by DNA sequencing (Beckman Coulter Genomics, Takeley, UK).

QRT-PCR data were analyzed using the qBase plus Software (Biogazelle, Ghent, Belgium). Cq values were transformed into normalized relative quantities (NRQs) based on several reference genes and after correcting for differences in amplification efficiency, using the approach described by Hellemans et al. (2007). To identify the reference genes best suited for calculating the required normalization factors (NFs), we used qBase to calculate two quality measures for the six reference genes mentioned above: the coefficient of variation of the normalized reference gene expression levels and the geNorm stability $M$-value. Subsequently, the data for another, less stable reference gene were integrated to give NFs, following the procedure described by Vandesompele et al. (2002). Using this stepwise approach, we determined that $C q$ data for SLC3OA6, CNOT11, and RPL19 were best suited for normalizing the HDGF data.

\section{In vivo embryo sample collection for protein and gene expression analysis}

Embryos were washed three times in PBS-polyvinylpyrrolidone and grouped according to their development stage (degenerated, morulae, blastocyst, expanded blastocyst, and hatched blastocyst). Only expanded blastocysts were further processed for qRT-PCR and IHC.

Embryos for IHC were fixed for $20 \mathrm{~min}$ at room temperature in $4 \%$ paraformaldehyde in $0.1 \mathrm{M}$ PBS ( $\mathrm{pH} 7.4$ ). Fixed embryos were stored in $0.1 \mathrm{M}$ PBS $(\mathrm{pH} 7.4)$ at $4{ }^{\circ} \mathrm{C}$ until use.

Table 1 Primers used to amplify regions of the HDGF gene in bovine endometrium and embryos or to amplify regions of reference genes in endometrium (SLC3OA6, CNOT11, and RPL19) and embryos (GAPDH, SDHA, and YWHAZ).

\begin{tabular}{llllcc}
\hline Symbols & Names & Accession nos & Primer sequences & \multicolumn{2}{c}{$\begin{array}{c}\text { Concentrations } \\
(\mu \mathrm{M})\end{array}$} \\
\hline HDGF & Hepatoma-derived growth factor & NM_175832.2 & GACCCACGAGACGGCATT & 0.3 \\
length $(\mathrm{bp})$
\end{tabular}


Embryos for qRT-PCR were snap frozen in Eppendorf DNA LoBind tubes (catalog no. 022431021, Eppendorf, Hamburg, Germany) and stored at $-145^{\circ} \mathrm{C}$ until use.

\section{Analysis of HDGF protein expression in bovine embryos by IHC}

HDGF protein expression was analyzed by IHC in day 8 blastocysts ( $n=8$ /condition) using a mouse polyclonal primary antibody against HDGF (43668, Abcam) as described previously (Muñoz et al. 2008). Serial optical sections were acquired by confocal laser scanning microscopy in order to characterize the pattern of HDGF expression. Negative controls using only secondary antibody were performed in parallel.

\section{Quantification of HDGF mRNA levels in bovine embryos by $q R T-P C R$}

RT-PCR was performed with embryos according to Khan et al. (2012), with some modifications. Briefly, RNAs from ten embryos were extracted using the Picopure RNA isolation Kit (Arcturus, Applied Biosystems) and incubated in extraction buffer containing a mixture of Luciferase RNA (Promega) and 16S-18S carrier RNA (Roche Diagnostics) at $42{ }^{\circ} \mathrm{C}$ for $30 \mathrm{~min}$, according to the manufacturer's instructions. Rates of mRNA recovery were evaluated by optical density measurement at a wavelength of $260 \mathrm{~nm}$ (using Nanodrop, Thermo Fisher Scientific, Madrid, Spain). cDNA was synthesized starting from the same number of 'equivalent embryos' in each sample and using the following conditions: $25^{\circ} \mathrm{C}$ for $5 \mathrm{~min}$ to allow annealing, $50{ }^{\circ} \mathrm{C}$ for $60 \mathrm{~min}$ for $\mathrm{RT}$, and $70{ }^{\circ} \mathrm{C}$ for $15 \mathrm{~min}$ to denature the enzyme.

PCR amplification was performed using the same primers targeting HDGF as were used for RT-PCR of endometrial samples. Data were analyzed using the qBase plus Software (Biogazelle). In contrast to the reference genes amplified in endometrial samples, the following reference genes were amplified in embryo samples, based on Goossens et al. (2005) (Table 1): GAPDH, SDHA, and the gene encoding tyrosine 3-monooxygenase/tryptophan 5-monooxygenase activation protein, zeta polypeptide ( $Y$ WHAZ). The qRT-PCRs were performed in a final volume of $25 \mu \mathrm{l}$ containing $10 \mu \mathrm{l}$ cDNA from 0.3 embryo equivalents. Cycling conditions were the same as for endometrial samples, except that 40 cycles of denaturation, annealing, and extension were performed. Amplified PCR fragments were verified by $1 \%$ agarose gel electrophoresis and ethidium bromide staining.

For amplification of each gene, all samples from a single experiment were analyzed on a single plate, and each PCR was performed in triplicate. Each experiment was conducted with five batches of embryos. The same calibration curve as for endometrial samples was used. Amplification efficiencies were $>80 \%$ and correlation coefficients were $>0.98$. Negative control amplifications lacking template were run in parallel for each gene, and no false positives were observed.

Ct values were transformed into NRQs using qBase plus (Biogazelle) as described for endometrial samples. Data were analyzed using the Wilcoxon-Mann-Whitney $U$ test.

\section{IVP of bovine embryos}

IVP embryos were obtained as described previously (Trigal et al. 2012), with minor modifications. Briefly, ovarian follicles with diameters of $3-8 \mathrm{~mm}$ from ovaries collected in a slaughterhouse were aspirated and cumulus-oocyte complexes recovered. After in vitro maturation for $24 \mathrm{~h}$, oocytes were subjected to IVF (day 0) using frozen/thawed semen from a single bull obtained through a swim-up procedure. Embryos were cultured in synthetic oviduct fluid (SOF) containing amino acids, citrate, and myo-inositol. SOF droplets were layered under mineral oil and incubated at $38.7{ }^{\circ} \mathrm{C}$ in an atmosphere of $5 \% \mathrm{CO}_{2}$ and $5 \% \mathrm{O}_{2}$ with saturated humidity. In order to produce morulae, SOF was supplemented with $6 \mathrm{mg} / \mathrm{ml}$ BSA (SOF-BSA) from days 1 to 5 or 6 . Within experiments (i.e. from day 5 or 6 onwards), embryos were cultured in SOF with $0.5 \mathrm{mg} / \mathrm{ml}$ polyvinyl alcohol (PVA) (SOF-PVA), in groups or singly, as single culture allows discarding paracrine effects from neighboring embryos. Group cultures comprised $50 \mu \mathrm{l}$ droplets with 25-35 embryos/drop. Single cultures were performed in $12 \mu \mathrm{l}$ droplets (Muñoz et al. 2014a,b,c).

\section{Differential cell counts and apoptosis in blastocysts}

Cell counts and apoptosis levels were measured in day 8 expanded blastocysts. Embryonic cells in the inner cell mass (ICM) and trophectoderm (TE) were differentially counted using a propidium iodide/bisbenzimide method (Trigal et al. 2012) with minor modifications.

TUNEL staining was carried out as described previously (Rodriguez et al. 2006), and nuclei were classified as showing apoptotic or necrotic morphology using the criteria of Gjørret et al. (2003). The numbers of apoptotic cells and necrotic cells were expressed as percentages of total cells to give the apoptotic index (AI) and necrotic index respectively. Al was measured in the ICM and in the TE.

Tissues were stained for caspase 3 using a procedure described by Wydooghe et al. (2001) and modified in our laboratory (Gómez et al. 2013). Caspase protein was detected in the cytoplasm of target embryos, while negative controls showed no positive staining.

\section{Synthesis of rHDGF}

Abyntek Laboratories (Derio, Bizkaia, Spain) produced rHDGF using the following procedure. Briefly, HDGF cDNA from bovine species was chemically synthesized with codon optimization for mammalian cell expression. A Flag tag sequence was inserted at the $5^{\prime}$-end of the coding region, followed by a Kozak sequence. The resulting Flag-HDGF cDNA was cloned into the pcDNA3.1 ( - ) expression vector (Life Technologies), which was transiently transfected into HEK293 cells. At $72 \mathrm{~h}$ after transfection, cells were harvested and HDGF protein was purified by affinity chromatography against the Flag tag. Protein purification was monitored by SDS-PAGE and WB against the Flag tag. 


\section{Proliferation assay of bovine fetal fibroblasts cultured with rHDGF}

Fibroblasts were obtained from a 3-month-old bovine fetus, passaged for multiplication, and stored in aliquots in a medium containing 90\% DMSO as described previously (Muñoz et al. 2008). For rHDF proliferation assay, thawed fibroblasts were routinely maintained in a basal medium (DMEM supplemented with $10 \%$ FCS, $1 \%$ non-essential amino acids, and $1 \%$ penicillin-streptomycin-amphotericin mixture) in a humidified incubator at $38.5^{\circ} \mathrm{C}$ in an atmosphere of $5 \% \mathrm{CO}_{2}$. Cells were treated with rHDGF in a medium with and without FCS at $24 \mathrm{~h}$ post-seeding and then cultured for $48 \mathrm{~h}$ in the presence of rHDGF. Real-time cell proliferation was measured using xCelligence System (Acea, Izasa, Barcelona, Spain). Serumcontaining and serum-free conditions (as intended for in vitro embryo culture) were used to test rHDGF cell proliferation activity. A 96-well plate was filled with $100 \mu \mathrm{l}$ basal media/well and equilibrated at room temperature for $30 \mathrm{~min}$. The plate was placed into a station cradle (housed in a humidified incubator at $38.5{ }^{\circ} \mathrm{C}$ in an atmosphere of $5 \% \mathrm{CO}_{2}$ ) to establish background reading. Cells were enumerated by Trypan blue staining and plated at a density of $1 \times 10^{4}$ cells/well in five replicates. Cells were allowed to settle for $30 \mathrm{~min}$ outside the incubator before returning the plate to the work station. Cell growth was monitored by electrical impedance measurements expressed as a normalized cell proliferation index (CPI).

\section{Experimental design}

Experiment 1: levels of HDGF $m R N A$ and protein in endometrium and embryos

This experiment aimed to explore the uterine and/or embryonic origins of HDGF. Endometrial tissue was analyzed by IHC to explore distribution and localization of HDGF protein, by WB to analyze HDGF levels and by qRT-PCR to measure HDGF mRNA levels. Analogously, three groups of seven expanded blastocysts (day 8) were analyzed by ICH and five pools of ten such blastocysts were analyzed by qRT-PCR. Blastocysts had been either entirely produced in vitro or transferred into cows on day 5 .

\section{Experiment 2: effect of rHDGF on bovine fibroblast cell proliferation assay}

We analyzed rHDGF bioactivity using a real-time cell proliferation assay. Several rHDGF concentrations $(0,0.1,1$, 10,100 , and $250 \mathrm{ng} / \mathrm{ml}$ ) were tested both in medium containing $10 \%$ FCS and in serum-free conditions (i.e. as intended to be used within embryo culture). Normalized CPI was calculated at $24 \mathrm{~h}$ (serum-containing conditions) and $48 \mathrm{~h}$ (serum-free conditions) as described for fetal fibroblasts.

\section{Experiment 3: effect of rHDGF on in vitro embryo development}

First, we analyzed group embryo cultures. On day 5, early morulae produced in SOF-BSA were selected and cultured to day 8 in SOF-PVA in the presence of rHDGF at 0, 0.1, 1, or $10 \mathrm{ng} / \mathrm{ml}$. Embryo development was recorded and cells were differentially counted in day 8 blastocysts.
Secondly, we compared embryo development over a shorter culture period (days 6-8) in SOF-PVA in the presence of 0,1 , or $100 \mathrm{ng} / \mathrm{ml}$ rHDGF. Approximately, 95\% of the embryos cultured were day 6 morulae, with the remainder early blastocysts. When the embryos had become day 8 blastocysts, their embryonic development was analyzed and differential cell counts were performed.

Finally, we tested the optimal culture conditions (i.e. $100 \mathrm{ng} / \mathrm{ml} \mathrm{rHDGF}$ in SOF-PVA) in individual embryo culture from days 6 to 8 . Individual culture allows discarding paracrine effects associated with embryo culture in groups. Data on embryo development were recorded daily, and day 8 blastocysts were differentially counted and subjected to TUNEL staining.

\section{Statistical analysis}

Sources of variation affecting fibroblast proliferation (CPI), and embryo development and recovery, i.e. cell counts, apoptosis (TUNEL staining), and expression of protein and mRNA (WB and qRT-PCR), were identified by fitting linear models using the Proc GLM module of SAS/STAT (version 9.2; SAS Institute, Cary, NC, USA). The models included the following fixed effects: experimental treatment, embryonic stage, animal (where appropriate), and replicate (technical and biological). LSMs and their errors ( \pm S.E.M.) were estimated for each level of fixed effects with a significant $F$ value. The Ryan-Einot-GabrielWelsch $Q$-test was used to compare the raw means of the levels from the fixed effects.
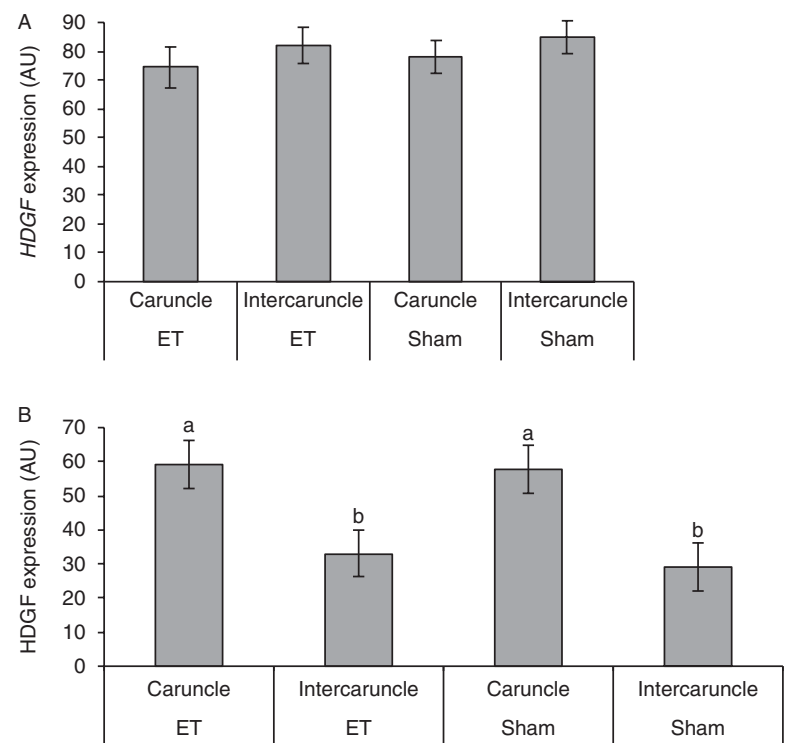

Figure 1 Real-time quantitative RT-PCR of HDGF mRNA (A) and western blot analysis of HDGF protein (B) from day 8 bovine endometrium collected from animals that received embryos (ET) and sham-treated control animals. Levels of mRNA and protein in caruncular and intercaruncular areas were similar between both groups of animals. HDGF protein was significantly more abundant in caruncular than in intercaruncular areas in both groups of animals. Results marked with different superscripts $(a, b)$ are significantly different $(P<0.001)$. Relative expression values are given in arbitrary units (AUs) and are plotted as the LSM \pm s.E.M. 

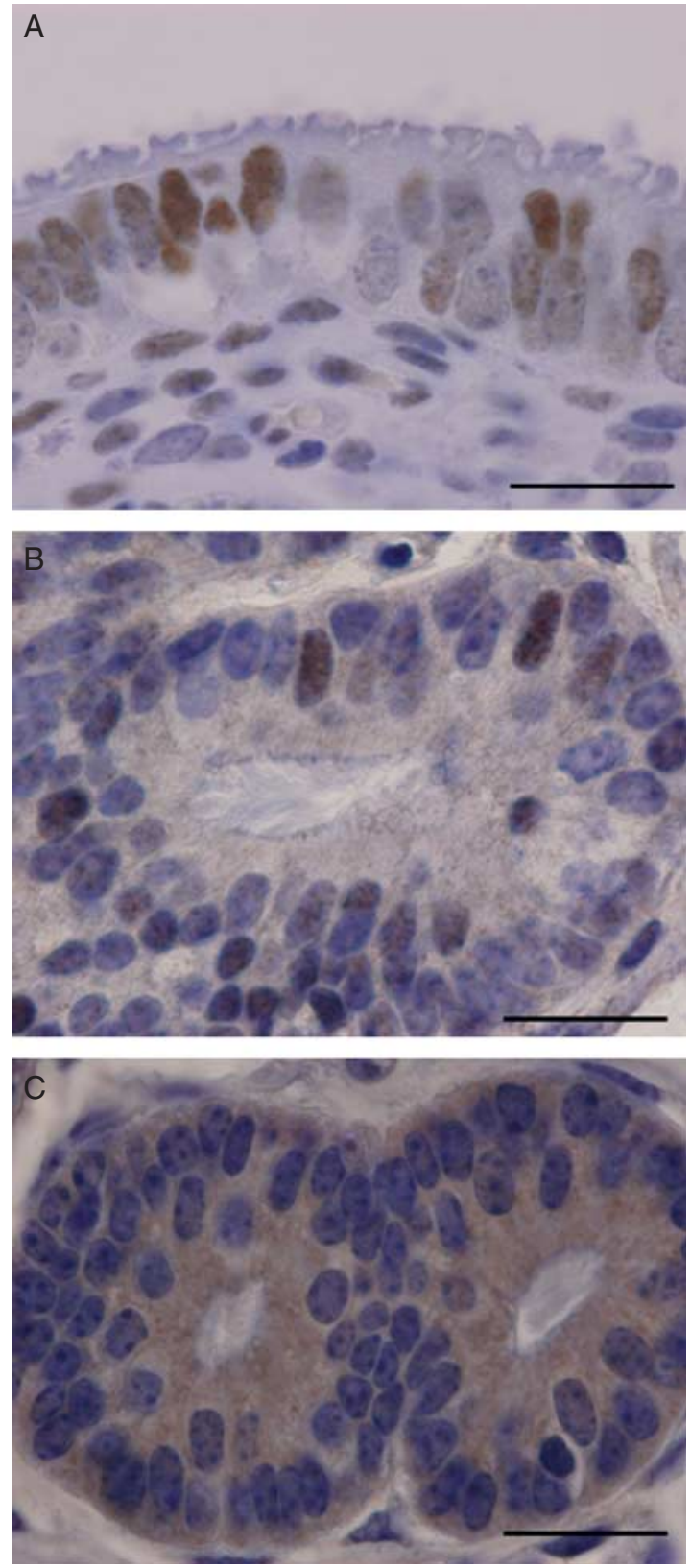

Figure 2 Representative immunohistochemical localization of HDGF protein in bovine endometrium. Positive labeling was found in the luminal (A) and glandular epithelial cells (B and C) and sub-epithelial stromal cells (A). In the luminal epithelium and superficial glands, immunostaining localized to the cell nuclei (A and B); in the deep glands, it localized to the apical cytoplasm adjacent to the glandular lumen (C). Scale bar, $20 \mu \mathrm{m}$.

\section{Results}

\section{Experiment 1: levels of HDGF $m R N A$ and protein in endometrium and embryos}

The average embryo recovery rate, expressed as the percentage of total embryos transferred, was 36.8 $\pm 4.0 \%$ (range $10-32, n=5$ cows). The live embryo recovery rate was $54.1 \pm 4.0 \%$ (range $8-16$ ).
Endometrial HDGF mRNA expression on day 8 was similar in caruncular and intercaruncular areas in the absence and presence of embryos $(P=0.66$; Fig. $1 \mathrm{~A})$, as were mRNA levels in cranial and middle horn regions ( $P=0.70$; data not shown). HDGF protein levels were also similar in caruncular and intercaruncular areas in both groups of animals $(P>0.10$; Fig. 1B). However, in both pregnant and cyclic animals, HDGF protein levels were significantly higher in caruncular areas $(56.2 \pm 4.3)$ than in intercaruncular ones (33.3 $\pm 4.4, P<0.001$ ).

Immunoreactive HDGF was detected in all endometrial samples. HDGF protein was localized to the nuclei of the luminal epithelium, sub-epithelial stroma, and superficial gland cells (Fig. 2A and B respectively). By contrast, localization of HDGF in deep uterine glands was observed in the cytoplasm (Fig. 2C). Interestingly, some sparse cells with strongly stained cytoplasm were detected in the caruncles (Supplementary Fig. 1, see section on supplementary data given at the end of this article). Negative control samples processed without any primary antibody showed no significant HDGF staining (Supplementary Fig. 2).

Relative abundance of HDGF mRNA, expressed in arbitrary units, was significantly lower in embryos recovered from the uterus $(0.60 \pm 0.08)$ than in embryos produced entirely in vitro $(1.0 \pm 0.08 ; P=0.016$; Fig. 3$)$. HDGF protein was detected in blastocysts after uterine passage (Fig. 4A) and in blastocysts produced entirely in vitro (Fig. 4D). In both cases, evaluation of serial optical sections analyzed by confocal laser scanning microscopy showed positive staining in the TE (Fig. 4C and F) but none in the ICM (Fig. 4B and E). Negative control samples processed without any primary antibody showed no significant HDGF staining (Supplementary Fig. 3, see section on supplementary data given at the end of this article).

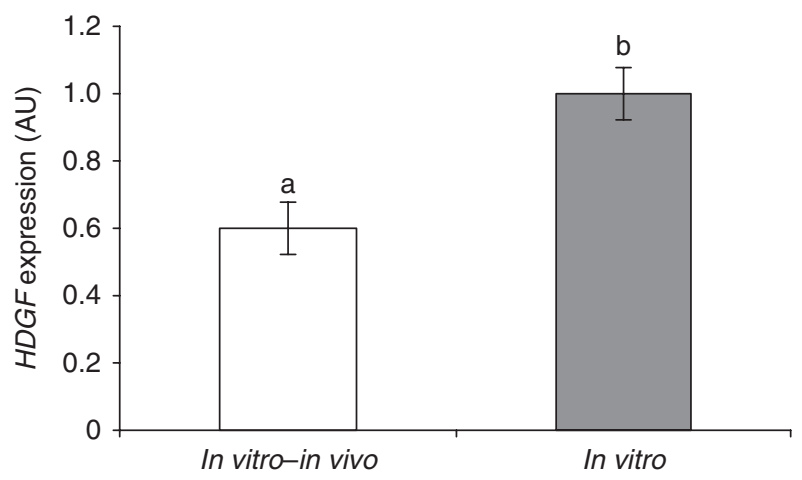

Figure 3 Real-time quantitative RT-PCR of HDGF mRNA in bovine embryos. Levels of mRNA were significantly lower in blastocysts after uterine passage (in vitro-in vivo) than in blastocysts that developed entirely in vitro (in vitro; ${ }^{\mathrm{a}, \mathrm{b}} P=0.016$ ). 

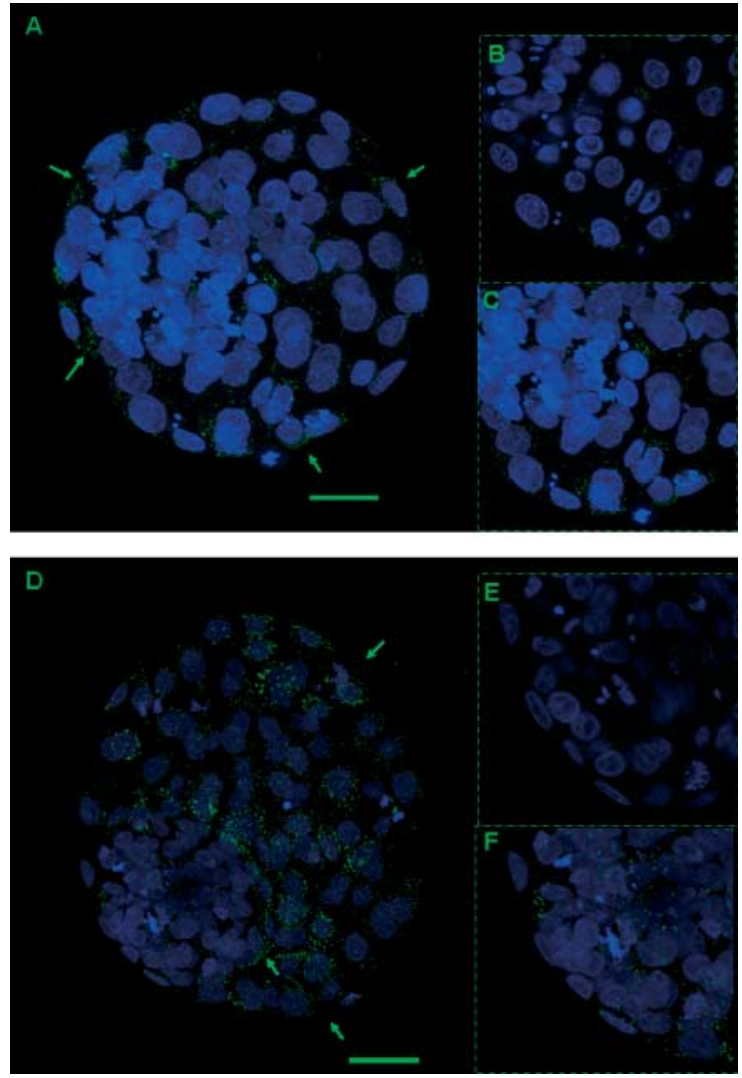

Figure 4 Immunofluorescence staining of HDGF protein in bovine embryos. HDGF was detected in blastocysts after uterine passage (A, B and C) and in blastocysts that developed entirely in vitro ( $D, E$ and $F$ ). HDGF localized to the trophectoderm (TE) cells (arrows, A and D; inserts, $\mathrm{C}$ and $\mathrm{F}$ ), based on staining with a mouse polyclonal antibody. Detailed inspection of single $z$-axis optical sections from different focal planes confirmed that HDGF was expressed exclusively in TE cells (inserts, $C$ and $\mathrm{F}$ ) and not in cells of the inner cell mass (inserts, B and E). Embryonic nuclei were counterstained with DAPI (blue). Scale bar, $25 \mu \mathrm{m}$.

\section{Experiment 2: effect of rHDGF on bovine fibroblast cell proliferation assay}

In the presence of serum, rHDGF concentrations ranging between 1 and $250 \mu \mathrm{g} / \mathrm{ml}$ significantly increased the CPI $(P<0.02$; Fig. 5A). In the absence of serum, only $1 \mu \mathrm{g} / \mathrm{ml}$ rHDGF showed a highly significant effect $(P<0.001$; Fig. 5B) on CPI. Representative real-time fibroblast cell growth curves are shown in Supplementary Fig. 4A, see section on supplementary data given at the end of this article (serum-containing) and Supplementary Fig. 4B (serum-free). Therefore, we initially selected $1 \mu \mathrm{g} / \mathrm{ml}$ rHDGF and its closer concentrations (i.e. 0.1 and $10 \mu \mathrm{g} /$ $\mathrm{ml}$ ) to analyze within in vitro embryo culture experiments.

\section{Experiment 3: effect of $r H D G F$ on in vitro embryo development}

We analyzed how adding rHDGF to the culture medium affects in vitro embryo development in SOF-PVA. First, we analyzed group cultures. On day 5, early morulae were selected and cultured up to day 8 in the presence of rHDGF at concentrations of $0,0.1,1$, or $10 \mathrm{ng} / \mathrm{ml}$ (Table 2). All rHDGF concentrations significantly reduced blastocyst expansion rates on day $7(P<0.01)$, but none of the rHDGF concentrations affected blastocyst development on day 8 . Nevertheless, 0,1 , and $10 \mathrm{ng} / \mathrm{ml} \mathrm{rHDGF}$ reduced day 8 hatching rates. Addition of rHDGF at any concentration did not significantly affect cell counts in the ICM or TE on day 8 (Table 3).

To gain more insight into whether the observed effects of rHDGF depend on embryo developmental stage, we repeated the experiments with day 6 morulae cultured to day 8 using rHDGF at a concentration of 1 or $100 \mathrm{ng} / \mathrm{ml}$ in SOF-PVA. We increased the upper concentration up to levels at which other uterine growth factors (i.e. EGF and IGF1) that activate the same downstream pathways as HDGF increased pregnancy rates using embryos cultured in similar conditions (Block \& Hansen 2007, Sakagami et al. 2012). Adding $100 \mathrm{ng} / \mathrm{ml} \mathrm{rHDGF}$ to the culture medium significantly increased the rate of formation of day 7 morulae and day 8 blastocyst and expanded blastocysts $(P<0.05$; Table 4$)$. Counts in TE and total cell numbers increased with $100 \mathrm{ng} / \mathrm{ml} \mathrm{rHDGF}$ (Table 5). The adverse effects on day 7 expansion rates observed when $1 \mathrm{ng} / \mathrm{ml}$ HDGF was added to the culture medium on day 5 were not observed when an equal
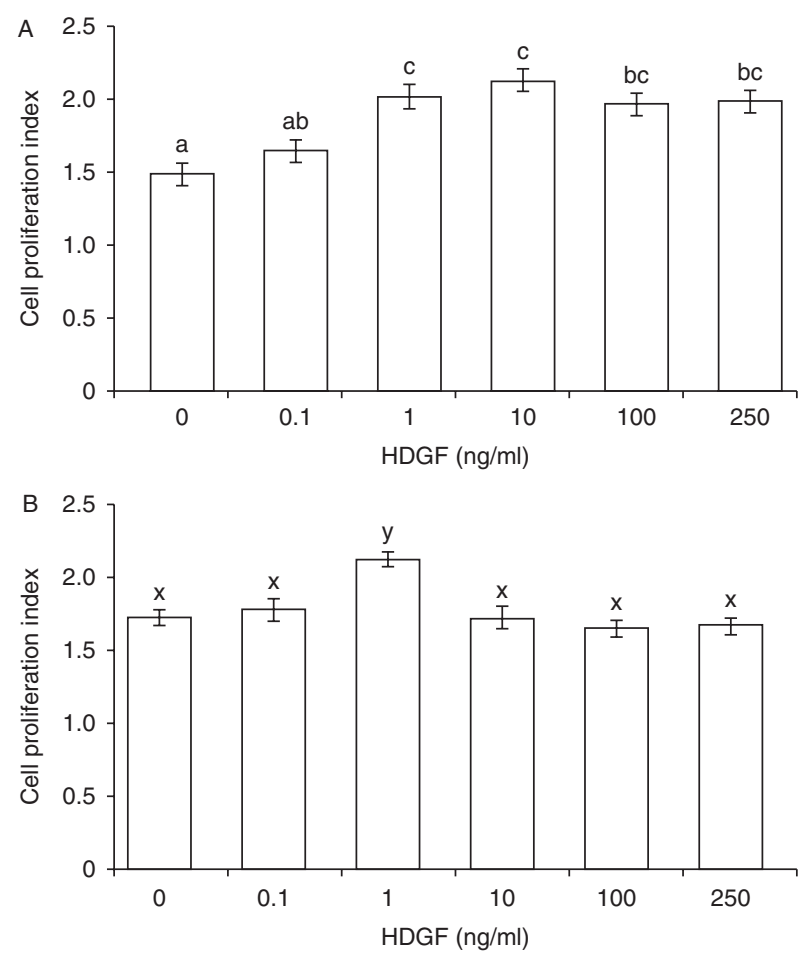

Figure 5 Cell proliferation index $(\mathrm{CPI})$ of fetal fibroblasts growing in cultures with several rHDGF concentrations in the presence $(A)$ and the absence (B) of $10 \%$ FCS. Cell growth was permanently monitored, and the $\mathrm{CPI}$ calculated at $48 \mathrm{~h}(\mathrm{~A})$ and $24 \mathrm{~h}(\mathrm{~B})$. Superscripts show significant differences: ${ }^{\mathrm{a}, \mathrm{b}, \mathrm{c}} \mathrm{P}<0.02 ;{ }^{\mathrm{x}, \mathrm{y}} \mathrm{P}<0.001$. 
Table 2 In vitro development of early bovine morulae cultured from days 5 to 8 in groups in synthetic oviduct fluid containing recombinant HDGF (rHDGF).

\begin{tabular}{|c|c|c|c|c|c|c|c|c|}
\hline \multirow[b]{2}{*}{ rHDGF $(\mathrm{ng} / \mathrm{ml})$} & \multirow[b]{2}{*}{$n$} & \multicolumn{2}{|c|}{ Morulae (\%) } & \multicolumn{2}{|c|}{ Day 7 blastocysts (\%) } & \multicolumn{3}{|c|}{ Day 8 blastocysts (\%) } \\
\hline & & Day 6 & Day 7 & Total & Expanded & Total & Expanded & Hatched \\
\hline 0 & 96 & $84.7 \pm 2.4$ & $67.0 \pm 3.3$ & $42.7 \pm 5.2$ & $19.2 \pm 2.0^{*}$ & $52.1 \pm 3.8$ & $33.2 \pm 4.9$ & $3.3 \pm 0.7^{\neq}$ \\
\hline 0.1 & 96 & $86.8 \pm 2.4$ & $60.7 \pm 3.3$ & $26.0 \pm 5.2$ & $5.8 \pm 2.0^{+}$ & $49.0 \pm 3.8$ & $25.2 \pm 4.9$ & $0.0^{\S}$ \\
\hline 1 & 97 & $85.6 \pm 2.5$ & $75.2 \pm 3.3$ & $38.0 \pm 5.2$ & $8.1 \pm 2.0^{+}$ & $56.7 \pm 3.8$ & $35.7 \pm 4.9$ & $0.1 \pm 0.7$ \\
\hline 10 & 97 & $88.3 \pm 2.4$ & $75.3 \pm 3.3$ & $41.5 \pm 5.2$ & $9.3 \pm 2.0^{\dagger}$ & $59.1 \pm 3.8$ & $34.5 \pm 4.9$ & $0.0^{\S}$ \\
\hline
\end{tabular}

$n$, day 5 cultured early morulae. Data were collected from four replicates. Values in the same column marked with different symbols indicate significant differences: ${ }^{*+\dagger} P<0.01$ and ${ }^{\ddagger, \S} P<0.05$.

concentration of growth factor was added on day 6 . Although not tested in the same experimental replicates, cell counts in the ICM were numerically lower in expanded blastocysts cultured in groups from day 5 onwards (Table 3) than from day 6 onwards (Table 5).

Then, we analyzed the effects of rHDGF on the development of individual embryo cultures from days 6 to 8 in SOF-PVA. This technique allows for efficient, non-invasive sex detection (Muñoz et al. 2014a) and prediction of pregnancy viability based on spectroscopic analysis of embryo-conditioned culture medium (Muñoz et al. 2014b,c).

Adding rHDGF to the culture medium led to a significantly higher day 7 morulae rate $(P<0.03)$ as well as a higher day 7 blastocyst rate $(P<0.01)$ (Table 6). Blastocyst and expanded blastocyst development tended to be higher $(P<0.07)$ in the presence of rHDGF. Addition of rHDGF to the culture medium (Table 7) significantly increased cell counts in the ICM and total cell counts $(P<0.03)$, and the increases observed in the TE tended to be significant $(P<0.06)$. Individual embryo cultures in our experiments showed similar levels of apoptosis based on TUNEL staining (data not shown).

\section{Discussion}

This study is the first detailed characterization of HDGF expression and function during early pregnancy in mammals. A previous work identified bovine HDGF in the UF (Muñoz et al. 2012), prompting us to ask whether the embryo and/or the mother express HDGF and how HDGF affects embryo development. The results of this study suggest that the presence of developing embryos does not significantly affect the levels of HDGF mRNA or protein in the endometrium. Nevertheless, HDGF mRNA and protein are detectable in embryos produced in vitro and in embryos exposed to the uterine environment. Exposing day 5 morulae to the uterus downregulates HDGF mRNA expression in recovered day 8 blastocysts to levels lower than those in embryos that developed entirely in vitro. Proliferation assay with bovine fetal fibroblasts demonstrated that rHDGF is a bioactive peptide. Experiments with embryos cultured individually or in groups in the presence of various concentrations of bioactive rHDGF indicate that this growth factor improves embryo development and cell counts in vitro. Our findings suggest that HDGF may act as a paracrine and/or autocrine factor to regulate embryo development in vivo.

Growing evidence points to the involvement of HDGF in controlling early embryo development, raising the question as to what molecule(s) triggers production of this growth factor in the first place. One candidate is hepatocyte growth factor (HGF), an angiogenic factor (Okada et al. 1999) that induces HDGF expression in cancer cells (Mao et al. 2008, Lee et al. 2010). In fact, the downstream effects of HGF may be mediated in part by HDGF induction of vascular endothelial growth factor (Mao et al. 2008, Lee et al. 2010) and angiogenesis via paracrine mechanisms (Sasaki et al. 2011, Thirant et al. 2012, Tsai et al. 2013).

To take into account the possibility that HDGF is regulated at transcriptional and/or post-transcriptional levels, we assayed levels of both mRNA and protein in our experiments. In this study, the presence of embryos did not alter endometrial HDGF mRNA expression in caruncular and intercaruncular areas, nor did it affect the localization of HDGF protein to cranial or middle horn regions. HDGF staining patterns only differed by structure: localization was primarily cytoplasmic with apparent secretion in deep uterine glands, while the protein localized to the nucleus in the luminal epithelium and superficial glands. In addition, some sparse positive cells were found in the caruncles. The lack of regulation of endometrial HDGF expression in the uterus by the embryo is intriguing, as $\mathrm{P} 4$ does not control HGF expression in the ruminant uterus either (Mitko et al. 2008, Satterfield et al. 2008). However,

Table 3 Differential cell counts in day 8 expanded blastocysts cultured in groups from days 5 to 8 in synthetic oviduct fluid containing PVA with recombinant HDGF (rHDGF).

\begin{tabular}{lcccc}
\hline $\begin{array}{l}\text { rHDGF } \\
(\mathrm{ng} / \mathrm{ml})\end{array}$ & $\boldsymbol{n}$ & ICM & TE & Total \\
\hline 0 & 20 & $14.4 \pm 1.9$ & $113.6 \pm 5.6$ & $128.7 \pm 5.7$ \\
0.1 & 19 & $14.0 \pm 2.0$ & $110.0 \pm 6.6$ & $123.7 \pm 6.0$ \\
1 & 29 & $15.4 \pm 1.6$ & $111.8 \pm 5.0$ & $131.1 \pm 4.7$ \\
10 & 29 & $15.6 \pm 1.6$ & $117.3 \pm 4.8$ & $133.2 \pm 4.7$ \\
\hline
\end{tabular}

ICM, inner cell mass; $n$, number of embryos; TE, trophectoderm. Data were collected from four replicates. None of the values within each column indicated significant differences from one another $(P>0.10)$. 
Table 4 In vitro development of bovine morulae cultured from days 6 to 8 in synthetic oviduct fluid with PVA containing recombinant HDGF (rHDGF).

\begin{tabular}{|c|c|c|c|c|c|c|c|}
\hline \multirow[b]{2}{*}{$\begin{array}{l}\text { rHDGF } \\
(\mathrm{ng} / \mathrm{ml})\end{array}$} & \multirow[b]{2}{*}{$n$} & \multirow[b]{2}{*}{$\begin{array}{c}\text { Day } 7 \\
\text { morulae (\%) }\end{array}$} & \multicolumn{2}{|c|}{ Day 7 blastocysts (\%) } & \multicolumn{3}{|c|}{ Day 8 blastocysts (\%) } \\
\hline & & & Total & Expanded & Total & Expanded & Hatched \\
\hline 0 & 139 & $81.8 \pm 2.1^{*}$ & $42.2 \pm 4.0$ & $13.8 \pm 2.6$ & $54.2 \pm 3.0^{\ddagger}$ & $39.0 \pm 2.9^{\ddagger}$ & $4.7 \pm 1.5$ \\
\hline 1 & 99 & $78.9 \pm 2.4^{*}$ & $47.4 \pm 4.7$ & $12.8 \pm 3.0$ & $67.2 \pm 3.4$ & $52.2 \pm 3.3$ & $8.4 \pm 1.8$ \\
\hline 100 & 99 & $96.8 \pm 2.4^{+}$ & $57.8 \pm 4.7$ & $18.2 \pm 3.0$ & $70.9 \pm 3.4^{\S}$ & $54.7 \pm 3.3^{\S}$ & $8.3 \pm 1.8$ \\
\hline
\end{tabular}

$n$, day 6 cultured embryos ( $90 \%$ morulae + early blastocysts). Data were collected from five replicates. Values in the same column with different symbols indicate significant differences: ${ }^{*}+\mathrm{t} P<0.01$ and ${ }^{\ddagger, \S} P<0.05$.

luminal and glandular epithelial cells express $\mathrm{HGF}$ receptor and epithelial c-met proto-oncogene (MET), under P4 regulation (Mitko et al. 2008, Satterfield et al. 2008). On the embryonic side, passage through the uterine tract led to reduced levels of HDGF mRNA in recovered day 8 blastocysts in comparison to those produced entirely in vitro. Interestingly, no differences were found in HDGF expression or distribution in TE cells, between both types of embryonic samples analyzed. In line with our findings, expression of MET has been localized to the ovine TE (Chen et al. 2000a,b).

We postulate that embryonal and uterine HDGF may act in an autocrine and/or paracrine way with the possible participation of HGF to induce HDGF synthesis and secretion in deep uterine glands and regulate HDGF gene expression. This crosstalk may lead the embryo to downregulate its own HDGF transcription to compensate for the presence of maternal HDGF.

In contrast to the cytoplasmic and secretory localization of HDGF in deep glands, we found the protein to localize to the nucleus in superficial glands and epithelium. This nuclear localization suggests that the protein was not secreted from these regions. Consistent with our findings, HDGF localizes to the nucleus and cytoplasm in human fibroblasts (Abouzied et al. 2004).

In addition to providing first evidence of endometrial and embryonic localization and gene expression of HDGF, our study demonstrates that the growth factor is potentially involved in regulating in vivo and in vitro development. We performed proliferation assays with rHDGF in more usual conditions with serum, whereby HDGF bioactivity has been previously shown with fibroblasts not only in other species (Klagsbrun et al. 1986, Abouzied et al. 2005, Wang et al. 2011), but also in defined conditions, as intended for embryo culture. Serum may provide carriers and cofactors necessary for GFs to exert their physiological effects (Francis 2010). However, a chemically defined medium is interesting for the normalization of embryo culture conditions and absence of sanitary risks associated with the compounds of animal origin. The effects of HDGF on in vitro embryo development depended on the developmental stage. When HDGF was added to group cultures of early morulae from day 5 onwards, blastocyst expansion on day 7 was severely reduced and blastocyst cell counts were unchanged. By contrast, adding HDGF to group cultures of late morulae on day 6 promoted embryo development and increased TE cell counts. Such timedependent effects of growth factors on in vitro embryo development have also been reported for FGF2, activin, CSF2, IGF1, TGF $\beta$ (TGFB), TGF $\alpha$ (TGFA), and PDGF (PDGFA; Larson et al. 1992a,b, Loureiro et al. 2009, Fields et al. 2011, Trigal et al. 2011, Dobbs et al. 2013). In fact, the developmental stage at which CSF2 and IGF1 are added to cultures strongly affects the yield and quality of the resulting blastocysts, as well as pregnancy and birth rates (Loureiro et al. 2009). A well-established explanation for such stage-specific effects relies on the timed expression of growth factor receptors in the embryo, which renders it responsive to uterine growth factors only during specific periods of development. There was also an apparent, side effect of the day and/or developmental stage of replacement of BSA by PVA on the ICM cells (day 5 vs day 6$)$. Thus, in group culture, ICM cell numbers were lower with PVA added on day 5 than on day 6 , suggesting that removal of protein from culture out of certain limits might compromise embryonic quality.

Our results suggest that HDGF helps to advance the day 6 morulae throughout blastulation. In bovine blastocysts, E-cadherin and vimentin are TE markers during the epithelial to mesenchymal transition (EMT; Yamakoshi et al. 2012), with each protein serving essential and specific roles at different stages of blastocyst development. Interestingly, HDGF downregulates E-cadherin expression and upregulates vimentin expression to help drive EMT in both healthy and cancer cells (Chen et al. 2012, Tsai et al. 2013). Future research should explore stage-dependent effects of

Table 5 Differential cell counts in day 8 expanded blastocysts cultured in groups from days 6 to 8 in synthetic oviduct fluid containing PVA with recombinant HDGF (rHDGF).

\begin{tabular}{lcccc}
\hline $\begin{array}{l}\text { rHDGF } \\
(\mathrm{ng} / \mathrm{ml})\end{array}$ & $\boldsymbol{n}$ & ICM & TE & Total \\
\hline 0 & 27 & $25.9 \pm 2.6$ & $115.3 \pm 5.2^{\|}$ & $138.6 \pm 5.8^{\ddagger}$ \\
1 & 37 & $27.4 \pm 2.2$ & $108.3 \pm 4.4^{*}$ & $132.9 \pm 5.2^{\ddagger}$ \\
100 & 38 & $23.2 \pm 2.7$ & $132.2 \pm 5.4^{+, \boldsymbol{q}}$ & $155.4 \pm 4.9^{\S}$ \\
\hline
\end{tabular}

ICM, inner cell mass; $n$, number of embryos; TE, trophectoderm. Data were collected from four replicates. Values in the same column with different symbols indicate significant differences: ${ }^{*,+} P<0.01$ and ${ }_{\neq, \$} P<0.05$ or a tendency, ${ }^{\prime \prime}, 9<0.07$. 
Table 6 In vitro development of bovine morulae cultured individually from days 6 to 8 in droplets of synthetic oviduct fluid with PVA containing $100 \mathrm{ng} / \mathrm{ml}$ recombinant HDGF (rHDGF).

\begin{tabular}{|c|c|c|c|c|c|c|c|c|c|}
\hline \multirow{2}{*}{$\begin{array}{l}\mathbf{r H D G F} \\
(\mathrm{ng} / \mathrm{ml})\end{array}$} & \multirow[b]{2}{*}{$n$} & \multirow{2}{*}{$\begin{array}{c}\text { Day } 7 \text { (\%) } \\
\text { Morulae } \\
\end{array}$} & \multicolumn{3}{|c|}{ Day 7 blastocysts (\%) } & \multicolumn{4}{|c|}{ Day 8 blastocysts (\%) } \\
\hline & & & Total & Blastocysts & Expanded & Total & Blastocysts & Expanded & Hatched \\
\hline $\begin{array}{l}0 \\
100 \\
\text { LSM }\end{array}$ & $\begin{array}{l}229 \\
230\end{array}$ & $\begin{array}{l}74.1^{\ddagger} \\
91.0^{\S} \\
\pm 4.5\end{array}$ & $\begin{array}{l}55.2 \\
68.4 \\
\pm 5.1\end{array}$ & $\begin{array}{l}32.2^{*} \\
49.5^{\dagger} \\
\pm 3.8\end{array}$ & $\begin{array}{r}15.3 \\
20.6 \\
2.8\end{array}$ & $\begin{array}{l}62.5 \\
76.7 \\
\pm 6.6\end{array}$ & $\begin{array}{c}52.1^{\|} \\
67.7^{\natural} \\
5.6\end{array}$ & $\begin{array}{c}37.2^{\|} \\
50.9^{9} \\
\pm 4.6\end{array}$ & $\begin{array}{c}6.4 \\
5.7 \\
\pm 1.6\end{array}$ \\
\hline
\end{tabular}

LSMs, least square means. $n$, day 6 cultured early morulae. Data were collected from 11 replicates. Values in the same column with different symbols indicate significant differences: ${ }^{*,+} P<0.01$ and ${ }^{\neq, \S} P<0.05$; or tends, ${ }^{\|,}, P<0.07$.

HDGF in bovine embryo cultures related to the timed expression of E-cadherin and/or vimentin.

Embryotropic effects of rHDGF were observed with both group and single cultures. Our IHC studies showing the presence of substantial HDGF in TE but no localization in the ICM suggest that HDGF directly stimulates TE proliferation, while we speculate that proliferative effects on the ICM, clearly observed in individual culture, are likely to be mediated by a second factor in a paracrine way. Our apparent finding that HDGF does not affect apoptosis is surprising, given that HDGF overexpression inhibits caspase 3 activity in cancer cells (Liao et al. 2010). However, consistent with our observations, in healthy mouse fibroblasts, HDGF is dispensable for apoptotic signaling (Gallitzendoerfer et al. 2008). Alternatively, this unexpected result may be an artifact reflecting the fact that a certain percentage of cells showing unequivocal morphological signs of apoptosis fail to show TUNEL staining (Leidenfrost et al. 2011).

HDGF appears to activate the PI3K/Akt (Kung et al. 2012), and/or ERK (Mao et al. 2008, Lee et al. 2010) and p38 MAPK pathways (Wang et al. 2011). Early bovine IVP embryos show active ERK and p38 MAPK pathways (Madan et al. 2005), and the ERK pathway appears to be capable of activating p38 MAPK downstream kinases in the absence of p38 MAPK activity to maintain development, showing functional redundancy. Accordingly, numerous uterine signaling factors promote bovine embryo growth in vitro by acting through the above pathways. These factors include EGF, TGF $\beta$, insulin, IGF1, FGF2, leukemia inhibitory factor (LIF), activin, and PDGF (Larson et al. 1992a,b, Loureiro et al. 2009, Bonilla et al. 2011, Fields et al. 2011, Trigal et al. 2011, Sakagami et al. 2012, Dobbs et al. 2013, Wydooghe et al. 2013, Cebrian-Serrano et al. 2014). Even small molecules in the uterus, such as retinoic acid, can also activate PI3K/Akt (Bastien et al. 2006) and ERK1/2 (Persaud et al. 2013). Interestingly, retinoic acid also improves bovine blastocyst development in vitro (Rodríguez et al. 2006, 2007a, Gómez et al. 2008). As shown with these factors, adding HDGF to culture medium can improve the performance of cultures of individual embryos, allowing studies not only for cow breeding per se but also for model studies of human embryo culture. These factors can also be used to treat cow donors that provide few viable oocytes by aspiration and hence require individual oocyte culturing (Hansen 2010, Wydooghe et al. 2013).

In our in vitro embryo culture study, we found that rHDGF showed embryotropic effects at a concentration of $100 \mathrm{ng} / \mathrm{ml}$, which is similar or close to the concentration dynamic range at which other growth factors increase pregnancy rates using embryos cultured in defined and undefined conditions. Examples include bovine embryo culture in the presence of BSA and recombinant bovine CSF2 $(10 \mathrm{ng} / \mathrm{ml}$; Loureiro et al. 2009), as well as bovine embryo culture in the presence of PVA and human IGF1 $(50 \mathrm{ng} / \mathrm{ml})$ and mouse EGF (100 ng/ml; Sakagami et al. 2012) or in the presence of BSA and recombinant human IGF1 (100 ng/ml; Block \& Hansen 2007). These growth factors were probably selected for inclusion in in vitro embryo production systems based on sequence homology with the bovine species. The pregnancy rates reported for these factors suggest functional redundancy even among factors from different species. Nevertheless, we recommend the use of homospecific growth factors based on the substantial differences we obtained in development and quality of bovine embryos in vitro depending on whether we used human or mouse LIF (Rodríguez et al. 2007b).

In this study, we have shown that HDGF is synthesized by the endometrium and embryo similarly and that it may act by both autocrine and paracrine mechanisms to promote early embryo development in vitro and probably in vivo. Adding rHDGF to IVP embryos increases blastocyst development and cell proliferation. These effects depend on the developmental stage at which the growth factor is added. HDGF seems to be an effective growth factor both in serum-containing

Table 7 Differential cell counts in day 8 expanded blastocysts cultured individually from days 6 to 8 in single drops of synthetic oviduct fluid supplemented with PVA in the presence of $100 \mathrm{ng} / \mathrm{ml}$ recombinant HDGF (rHDGF).

\begin{tabular}{lcccc}
\hline rHDGF $(\mathrm{ng} / \mathrm{ml})$ & $\boldsymbol{n}$ & ICM & TE & Total cells \\
\hline 0 & 23 & $18.0 \pm 2.3$ & $99.3 \pm 7.1$ & $117.0 \pm 6.9$ \\
100 & 19 & $25.1 \pm 2.4$ & $118.0 \pm 7.4$ & $139.7 \pm 7.8$ \\
$P$ value & & 0.03 & 0.06 & 0.03 \\
\hline
\end{tabular}

ICM, inner cell mass; $n$, number of blastocysts; TE, trophectoderm. Data were collected from four replicates. 
medium and also in defined culture conditions, which is advantageous for media standardization and optimization and individual tracking of cultured embryos.

\section{Supplementary data}

This is linked to the online version of the paper at http://dx.doi. org/10.1530/REP-14-0304.

\section{Declaration of interest}

The authors declare that there is no conflict of interest that could be perceived as prejudicing the impartiality of the research reported.

\section{Funding}

This work was supported by the fund provided by the Spanish Ministry of Science and Innovation (MICINN, projects AGL2012-37772 and AGL2009-10059) and by FEDER. M Muñoz is supported by grant MICINN-RYC08-03454; E Correia-Álvarez, by grant MEC-FPU-AP2009-5265; and O Sandra, by grant ANR-08-GENM-037. The authors are members of the COST Action FA1201 Epiconcept: Epigenetics and Periconception Environment.

\section{Acknowledgements}

The authors are grateful to Dr M Avilés for valuable technical and scientific support, to $\mathrm{P}$ Bolifraud and $\mathrm{C}$ Eozenou for assistance with qRT-PCR experiments, to M García-Ocaña, from SCTS in Oviedo University for performing proliferation assay, to I Fernández for his assistance in artwork, and to A Chapin Rodríguez for help in revising the manuscript.

\section{References}

Abouzied MM, Baader SL, Dietz F, Kappler J, Gieselmann V \& Franken S 2004 Expression patterns and different subcellular localization of the growth factors HDGF (hepatoma-derived growth factor) and HRP-3 (HDGF-related protein-3) suggest functions in addition to their mitogenic activity. Biochemical Journal 378 169-176. (doi:10.1042/BJ20030916)

Abouzied MM, El-Tahir HM, Prenner L, Häberlein H, Gieselmann V \& Franken S 2005 Hepatoma-derived growth factor. Significance of amino acid residues 81-100 in cell surface interaction and proliferative activity. Journal of Biological Chemistry 280 10945-10954. (doi:10.1074/jbc. M414652200)

Bastien J, Plassat JL, Payrastre B \& Rochette-Egly C 2006 The phosphoinositide 3-kinase/Akt pathway is essential for the retinoic acid-induced differentiation of F9 cells. Oncogene 25 2040-2047. (doi:10.1038/sj.onc.1209241)

Bernard K, Litman E, Fitzpatrick JL, Shellman YG, Argast G, Polvinen K, Everett AD, Fukasawa K, Norris DA, Ahn NG et al. 2003 Functional proteomic analysis of melanoma progression. Cancer Research 63 $6716-6725$.

Block J \& Hansen PJ 2007 Interaction between season and culture with insulin-like growth factor- 1 on survival of in vitro produced embryos following transfer to lactating dairy cows. Theriogenology 67 1518-1529. (doi:10.1016/j.theriogenology.2007.03.012)
Block J, Hansen PJ, Loureiro B \& Bonilla L 2011 Improving post-transfer survival of bovine embryos produced in vitro: actions of insulin-like growth factor- 1 , colony stimulating factor- 2 and hyaluronan. Theriogenology 76 1602-1609. (doi:10.1016/j.theriogenology.2011.07.025)

Bonilla AQ, Ozawa M \& Hansen PJ 2011 Timing and dependence upon mitogen-activated protein kinase signaling for pro-developmental actions of insulin-like growth factor 1 on the preimplantation bovine embryo. Growth Hormone \& IGF Research 21 107-111. (doi:10.1016/ j.ghir.2011.03.003)

Cebrian-Serrano A, Salvador I \& Silvestre MA 2014 Beneficial effect of two culture systems with small groups of embryos on the development and quality of in vitro-produced bovine embryos. Anatomia, Histologia, Embryologia 43 22-30. (doi:10.1111/ahe.12043)

Chang KC, Tai MH, Lin JW, Wang CC, Huang $\mathrm{CC}$, Hung $\mathrm{CH}$, Chen $\mathrm{CH}$, Lu SN, Lee CM, Changchien CS et al. 2007 Hepatoma-derived growth factor is a novel prognostic factor for gastrointestinal stromal tumors. International Journal of Cancer 121 1059-1065. (doi:10.1002/ijc.22803)

Chen C, Spencer TE \& Bazer FW 2000a Expression of hepatocyte growth factor and its receptor c-met in the ovine uterus. Biology of Reproduction 62 1844-1850. (doi:10.1095/biolreprod62.6.1844)

Chen C, Spencer TE \& Bazer FW 2000b Fibroblast growth factor-10: a stromal mediator of epithelial function in the ovine uterus. Biology of Reproduction 63 959-966. (doi:10.1095/biolreprod63.3.959)

Chen SC, Kung ML, Hu TH, Chen HY, Wu JC, Kuo HM, Tsai HE, Lin YW, Wen ZH, Liu JK et al. 2012 Hepatoma-derived growth factor regulates breast cancer cell invasion by modulating epithelial-mesenchymal transition. Journal of Pathology 228 158-169. (doi:10.1002/path.3988)

Dobbs KB, Khan FA, Sakatani M, Moss JI, Ozawa M, Ealy AD \& Hansen PJ 2013 Regulation of pluripotency of inner cell mass and growth and differentiation of trophectoderm of the bovine embryo by colony stimulating factor 2. Biology of Reproduction 89 141. (doi:10.1095/ biolreprod.113.113183)

Enomoto H, Yoshida K, Kishima Y, Kinoshita T, Yamamoto M, Everett AD, Miyajima A \& Nakamura H 2002 Hepatoma-derived growth factor is highly expressed in developing liver and promotes fetal hepatocyte proliferation. Hepatology 36 1519-1527. (doi:10.1002/hep.18403 60629)

Everett AD 2001 Identification, cloning, and developmental expression of hepatoma-derived growth factor in the developing rat heart. Developmental Dynamics 222 450-458. (doi:10.1002/dvdy.1204)

Everett AD, Stoops T \& McNamara CA 2001 Nuclear targeting is required for hepatoma-derived growth factor-stimulated mitogenesis in vascular smooth muscle cells. Journal of Biological Chemistry 276 37564-37568. (doi:10.1074/jbc.M105109200)

Fields SD, Hansen PJ \& Ealy AD 2011 Fibroblast growth factor requirements for in vitro development of bovine embryos. Theriogenology 75 1466-1475. (doi:10.1016/j.theriogenology.2010.12.007)

Francis GL 2010 Albumin and mammalian cell culture: implications for biotechnology applications. Cytotechnology 62 1-16. (doi:10.1007/ s10616-010-9263-3)

Gallitzendoerfer R, Abouzied MM, Hartmann D, Dobrowolski R, Gieselmann V \& Franken S 2008 Hepatoma-derived growth factor (HDGF) is dispensable for normal mouse development. Developmental Dynamics 237 1875-1885. (doi:10.1002/dvdy.21589)

Gjørret JO, Knijn HM, Dieleman SJ, Avery B, Larsson LI \& MaddoxHyttel P 2003 Chronology of apoptosis in bovine embryos produced in vivo and in vitro. Biology of Reproduction 69 1193-1200. (doi:10. 1095/biolreprod.102.013243)

Gómez E, Rodríguez A, Muñoz M, Caamaño JN, Carrocera S, Martín D, Facal N \& Díez C 2008 Development and quality of bovine morulae cultured in serum-free medium with specific retinoid receptor agonists. Reproduction, Fertility, and Development 20 884-891. (doi:10.1071/ RD08103)

Gómez E, Caamaño JN, Corrales FJ, Díez C, Correia-Álvarez E, Martín D, Trigal B, Carrocera S, Mora MI, Pello-Palma J et al. 2013 Embryonic sex induces differential expression of proteins in bovine uterine fluid. Journal of Proteome Research 12 1199-1210. (doi:10.1021/pr300845e)

Goossens K, Van Poucke M, Van Soom A, Vandesompele J, Van Zeveren A \& Peelman L 2005 Selection of reference genes for quantitative real-time PCR in bovine preimplantation embryos. BMC Developmental Biology 5 27. (doi:10.1186/1471-213X-5-27) 
Gopichandran N \& Leese HJ 2006 The effect of paracrine/autocrine interactions on the in vitro culture of bovine preimplantation embryos. Reproduction 131 269-277. (doi:10.1530/rep.1.00677)

Hansen PJ 2010 Medawar redux - an overview on the use of farm animal models to elucidate principles of reproductive immunology. American Journal of Reproductive Immunology 64 225-230. (doi:10.1111/j.16000897.2010.00900.x)

Hellemans J, Mortier G, De Paepe A, Speleman F \& Vandesompele J 2007 $q$ Base relative quantification framework and software for management and automated analysis of real-time quantitative PCR data. Genome Biology 8 R19. (doi:10.1186/gb-2007-8-2-r19)

Hu TH, Huang CC, Liu LF, Lin PR, Liu SY, Chang HW, Changchien CS, Lee CM, Chuang JH \& Tai MH 2003 Expression of hepatoma-derived growth factor in hepatocellular carcinoma. Cancer 98 1444-1456. (doi:10.1002/cncr.11653)

Khan DR, Dubé D, Gall L, Peynot N, Ruffini S, Laffont L, Le Bourhis D, Degrelle S, Jouneau A \& Duranthon V 2012 Expression of pluripotency master regulators during two key developmental transitions: EGA and early lineage specification in the bovine embryo. PLOS ONE 7 e34110. (doi:10.1371/journal.pone.0034110)

Klagsbrun M, Sasse J, Sullivan R \& Smith JA 1986 Human tumor cells synthesize an endothelial cell growth factor that is structurally related to basic fibroblast growth factor. PNAS 83 2448-2452. (doi:10.1073/pnas. 83.8.2448)

Kung ML, Tsai HE, Hu TH, Kuo HM, Liu LF, Chen SC, Lin PR, Ma YL, Wang EM, Liu GS et al. 2012 Hepatoma-derived growth factor stimulates podosome rosettes formation in NIH/3T3 cells through the activation of phosphatidylinositol 3-kinase/Akt pathway. Biochemical and Biophysical Research Communications 425 169-176. (doi:10.1016/j.bbrc. 2012.07.060)

Larson RC, Ignotz GG \& Currie WB 1992a Transforming growth factor $\beta$ and basic fibroblast growth factor synergistically promote early bovine embryo development during the fourth cell cycle. Molecular Reproduction and Development 33 432-435. (doi:10.1002/mrd.1080330409)

Larson RC, Ignotz GG \& Currie WB $1992 b$ Platelet derived growth factor (PDGF) stimulates development of bovine embryos during the fourth cell cycle. Development 115 821-826.

Lee KH, Choi EY, Kim MK, Lee SH, Jang BI, Kim TN, Kim SW, Kim SW, Song SK, Kim JR et al. 2010 Hepatoma-derived growth factor regulates the bad-mediated apoptotic pathway and induction of vascular endothelial growth factor in stomach cancer cells. Oncology Research 19 67-76. (doi:10.3727/096504010X12864748215043)

Leidenfrost S, Boelhauve M, Reichenbach M, Güngör T, Reichenbach HD, Sinowatz F, Wolf E \& Habermann FA 2011 Cell arrest and cell death in mammalian preimplantation development: lessons from the bovine model. PLOS ONE 6 e22121. (doi:10.1371/journal.pone. 0022121)

Liao F, Liu M, Lv L \& Dong W 2010 Hepatoma-derived growth factor promotes the resistance to anti-tumor effects of nordihydroguaiaretic acid in colorectal cancer cells. European Journal of Pharmacology 645 55-62. (doi:10.1016/j.ejphar.2010.07.033)

Lim KT, Jang G, Ko KH, Lee WW, Park HJ, Kim JJ, Lee SH, Hwang WS, Lee BC \& Kang SK 2007 Improved in vitrobovine embryo development and increased efficiency in producing viable calves using defined media. Theriogenology 67 293-302. (doi:10.1016/j.theriogenology.2006.07.011)

Loureiro B, Bonilla L, Block J, Fear JM, Bonilla AQ \& Hansen PJ 2009 Colony-stimulating factor 2 (CSF-2) improves development and posttransfer survival of bovine embryos produced in vitro. Endocrinology 150 5046-5054. (doi:10.1210/en.2009-0481)

Loureiro B, Block J, Favoreto MG, Carambula S, Pennington KA, Ealy AD \& Hansen PJ 2011 Consequences of conceptus exposure to colonystimulating factor 2 on survival, elongation, interferon- $\tau$ secretion, and gene expression. Reproduction 141 617-624. (doi:10.1530/REP10-0511)

Madan P, Calder MD \& Watson AJ 2005 Mitogen-activated protein kinase (MAPK) blockade of bovine preimplantation embryogenesis requires inhibition of both p38 and extracellular signal-regulated kinase (ERK) pathways. Reproduction 130 41-51. (doi:10.1530/rep. 1.00554)

Mansouri-Attia N, Aubert J, Reinaud P, Giraud-Delville C, Taghouti G, Galio L, Everts RE, Degrelle S, Richard C, Hue I et al. 2009 Gene expression profiles of bovine caruncular and intercaruncular endometrium at implantation. Physiological Genomics 39 14-27. (doi:10.1152/ physiolgenomics.90404.2008)

Mao J, Xu Z, Fang Y, Wang H, Xu J, Ye J, Zheng S \& Zhu Y 2008 Hepatoma-derived growth factor involved in the carcinogenesis of gastric epithelial cells through promotion of cell proliferation by Erk1/2 activation. Cancer Science 99 2120-2127. (doi:10.1111/j.1349-7006. 2008.00928.x)

Mitko K, Ulbrich SE, Wenigerkind H, Sinowatz F, Blum H, Wolf E \& Bauersachs S 2008 Dynamic changes in messenger RNA profiles of bovine endometrium during the oestrous cycle. Reproduction 135 225-240. (doi:10.1530/REP-07-0415)

Muñoz M, Peirson SN, Hankins MW \& Foster RG 2005 Long-term constant light induces constitutive elevated expression of mPER2 protein in the murine SCN: a molecular basis for Aschoff's rule? Journal of Biological Rhythms 20 3-15. (doi:10.1177/0748730404272858)

Muñoz M, Rodriguez A, De Frutos C, Caamano JN, Diez C, Facal N \& Gomez E 2008 Conventional pluripotency markers are unspecific for bovine embryonic-derived cell-lines. Theriogenology 69 1159-1164. (doi:10.1016/j.theriogenology.2008.02.014)

Muñoz M, Corrales FJ, Caamaño JN, Díez C, Trigal B, Mora MI, Martín D, Carrocera S \& Gómez E 2012 Proteome of the early embryo-maternal dialogue in the cattle uterus. Journal of Proteome Research 11 751-766. (doi:10.1021/pr200969a)

Muñoz M, Uyar A, Correia E, Díez C, Fernandez-Gonzalez A, Caamaño JN, Trigal B, Carrocera S, Seli E \& Gomez E 2014a Noninvasive assessment of embryonic sex in cattle by metabolic fingerprinting of in vitro culture medium. Metabolomics 443 451. (doi:10.1007/ s11306-013-0587-9)

Muñoz M, Uyar A, Correia E, Ponsart C, Guyader-Joly C, Martínez-Bello D, Marquant-Le Guienne B, Fernandez-Gonzalez A, Díez C, Caamaño JN et al. $2014 \mathrm{~b}$ Metabolomic prediction of pregnancy viability in superovulated cattle embryos and recipients with Fourier transform infrared spectroscopy. BioMed Research International 2014 608579. (doi:10. 1155/2014/608579)

Muñoz M, Uyar A, Correia E, Díez C, Fernandez-Gonzalez A, Caamaño JN, Martínez-Bello D, Trigal B, Humblot P, Ponsart C et al. 2014c Prediction of pregnancy viability in bovine in vitro produced embryos and recipient plasma with Fourier transform infrared spectroscopy. Journal of Dairy Science. In press. (doi:10.3168/jds.2014-8067)

Nakamura H, Izumoto Y, Kambe H, Kuroda T, Mori T, Kawamura K, Yamamoto H \& Kishimoto T 1994 Molecular cloning of complementary DNA for a novel human hepatoma-derived growth factor. Its homology with high mobility group-1 protein. Journal of Biological Chemistry 269 25143-25149.

Okada M, Matsumori A, Ono K \& Miyamoto T 1999 Hepatocyte growth factor is a major mediator in heparin-induced angiogenesis. Biochemical and Biophysical Research Communications 255 80-87. (doi:10.1006/ bbrc.1999.0150)

Oliver JA \& Al-Awqati Q 1998 An endothelial growth factor involved in rat renal development. Journal of Clinical Investigation 102 1208-1219. (doi:10.1172/JCI785)

Persaud SD, Lin YW, Wu CY, Kagechika H \& Wei LN 2013 Cellular retinoic acid binding protein I mediates rapid non-canonical activation of ERK1/2 by all-trans retinoic acid. Cellular Signalling 25 19-25. (doi:10.1016/ j.cellsig.2012.09.002)

Rodríguez A, Diez C, Ikeda S, Royo LJ, Caamaño JN, Alonso-Montes C, Goyache F, Alvarez I, Facal N \& Gomez E 2006 Retinoids during the in vitro transition from bovine morula to blastocyst. Human Reproduction 21 2149-2157. (doi:10.1093/humrep/del099)

Rodríguez A, Díez C, Caamaño JN, de Frutos C, Royo LJ, Muñoz M, Ikeda S, Facal N, Alvarez-Viejo M \& Gómez E 2007a Retinoid receptorspecific agonists regulate bovine in vitro early embryonic development, differentiation and expression of genes related to cell cycle arrest and apoptosis. Theriogenology 68 1118-1127. (doi:10.1016/j.theriogenology.2007.08.007)

Rodríguez A, De Frutos C, Díez C, Caamaño JN, Facal N, Duque P, GarcíaOchoa C \& Gómez E 2007 b Effects of human versus mouse leukemia inhibitory factor on the in vitro development of bovine embryos. Theriogenology 67 1092-1095. (doi:10.1016/j.theriogenology.2006. 11.015) 
Sakagami N, Umeki H, Nishino O, Uchiyama H, Ichikawa K, Takeshita K, Kaneko E, Akiyama K, Kobayashi S \& Tamada H 2012 Normal calves produced after transfer of embryos cultured in a chemically defined medium supplemented with epidermal growth factor and insulin-like growth factor I following ovum pick up and in vitro fertilization in Japanese black cows. Journal of Reproduction and Development $\mathbf{5 8}$ 140-146. (doi:10.1262/jrd.11-050M)

Sasaki Y, Negishi H, Idogawa M, Yokota I, Koyama R, Kusano M, Suzuki H, Fujita M, Maruyama R, Toyota M et al. 2011 p53 negatively regulates the hepatoma growth factor HDGF. Cancer Research 71 7038-7047. (doi:10.1158/0008-5472.CAN-11-1053)

Satterfield MC, Hayashi K, Song G, Black SG, Bazer FW \& Spencer TE 2008 Progesterone regulates FGF10, MET, IGFBP1, and IGFBP3 in the endometrium of the ovine uterus. Biology of Reproduction 79 1226-1236. (doi:10.1095/biolreprod.108.071787)

Thirant C, Galan-Moya EM, Dubois LG, Pinte S, Chafey P, Broussard C, Varlet P, Devaux B, Soncin F, Gavard J et al. 2012 Differential proteomic analysis of human glioblastoma and neural stem cells reveals HDGF as a novel angiogenic secreted factor. Stem Cells 30 845-853. (doi:10.1002/ stem.1062)

Trigal B, Gómez E, Díez C, Caamaño JN, Martín D, Carrocera S \& Muñoz M 2011 In vitro development of bovine embryos cultured with activin A. Theriogenology 75 584-588. (doi:10.1016/j.theriogenology. 2010.09.010)

Trigal B, Gómez E, Caamaño JN, Muñoz M, Moreno J, Carrocera S, Martín D \& Diez C 2012 In vitro and in vivo quality of bovine embryos in vitro produced with sex-sorted sperm. Theriogenology 78 1465-1475. (doi:10.1016/j.theriogenology.2012.06.018)

Tsai HE, Wu JC, Kung ML, Liu LF, Kuo LH, Kuo HM, Chen SC, Chan EC, Wu CS, Tai MH et al. 2013 Up-regulation of hepatoma-derived growth factor facilities tumor progression in malignant melanoma. PLOS ONE 8 e59345. (doi:10.1371/journal.pone.0059345)

Vandesompele J, De Preter K, Pattyn F, Poppe B, Van Roy N, De Paepe A \& Speleman F 2002 Accurate normalization of real-time quantitative RT-PCR data by geometric averaging of multiple internal control genes. Genome Biology 3 RESEARCH0034. (doi:10.1186/gb-2002-3-7-research0034)
Wang CH, Davamani F, Sue SC, Lee SC, Wu PL, Tang FM, Shih C, Huang TH \& Wu WG 2011 Cell surface heparan sulfates mediate internalization of the PWWP/HATH domain of HDGF via macropinocytosis to finetune cell signalling processes involved in fibroblast cell migration. Biochemical Journal 433 127-138. (doi:10.1042/BJ20100589)

Wydooghe E, Vandaele L, Beek J, Favoreel H, Heindryckx B, De Sutter P \& Van Soom A 2001 Differential apoptotic staining of mammalian blastocysts based on double immunofluorescent CDX2 and active caspase-3 staining. Analytical Biochemistry 416 228-230. (doi:10. 1016/j.ab.2011.05.033)

Wydooghe E, Heras S, Dewulf J, Piepers S, Van den Abbeel E, De Sutter P, Vandaele L \& Van Soom A 2013 Replacing serum in culture medium with albumin and insulin, transferrin and selenium is the key to successful bovine embryo development in individual culture. Reproduction, Fertility, and Development 26 717-724. (doi:10.1071/RD13043)

Yamakoshi S, Bai R, Chaen T, Ideta A, Aoyagi Y, Sakurai T, Konno T \& Imakawa K 2012 Expression of mesenchymal-related genes by the bovine trophectoderm following conceptus attachment to the endometrial epithelium. Reproduction 143 377-387. (doi:10.1530/REP-110364)

Yang Y, Li H, Zhang F, Shi H, Zhen T, Dai S, Kang L, Liang Y, Wang J \& Han A 2013 Clinical and biological significance of hepatoma-derived growth factor in Ewing's sarcoma. Journal of Pathology 231 323-334.

Zhao J, Yu H, Lin L, Tu J, Cai L, Chen Y, Zhong F, Lin C, He F \& Yang P 2011 Interactome study suggests multiple cellular functions of hepatomaderived growth factor (HDGF). Journal of Proteomics 75 588-602. (doi:10.1016/j.jprot.2011.08.021)

Received 27 March 2014

First decision 28 April 2014

Revised manuscript received 11 June 2014

Accepted 9 July 2014 